\title{
A fluorimetric method for red blood cell sorbitol dehydrogenase activity
}

\author{
G VACA, P ZUÑIIGA, C MEDINA, R ALONSO, G GONZÁLEZ-QUIROGA, \\ RI ORTIZ-DE-LUNA, JM CANTÚ
}

From the División de Genética, Subjefatura de Investigación Científica, Unidad de Investigación Biomédica, Centro Médico de Occidente, Instituto Mexicano del Seguro Social, Apartado Postal 1-3838, Guadalajara, Jalisco, Mexico

SUMMARY A new fluorimetric method for the quantification of red blood cell (RBC) sorbitol dehydrogenase is described. It is based on the oxidation of sorbitol to fructose, in presence of $\mathrm{NAD}^{+}$, catalysed by the RBC-sorbitol dehydrogenase. The quantity of NADH formed is then measured in a filter fluorimeter. Comparison with an indirect spectrophotometric assay yielded good correlation; however, the present method offers several advantages: it is more rapid, simple and inexpensive. It should be useful to screen for sorbitol dehydrogenase deficiency in large numbers of individuals, particularly patients with diabetes or cataracts.

The sorbitol pathway involves two enzymes: aldose reductase (EC 1.1.1.21) and sorbitol dehydrogenase (EC 1.1.1.14). Aldose reductase catalyses the conversion of glucose and galactose to sorbitol and galactitol, respectively, whereas sorbitol dehydrogenase converts sorbitol to fructose:

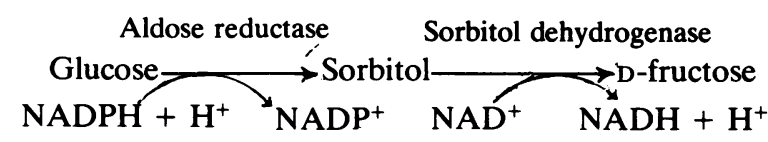

The importance of this pathway in "sugar-cataract" formation has been well established since sorbitol and galactitol are involved in the pathogenesis of diabetic and galactosaemic cataracts, respectively, in both experimental animals and humans (for review, see van Heyningen). ${ }^{1}$ Since human red blood cells (RBC) have the metabolic capacity for glucosesorbitol-fructose conversion, ${ }^{2-7}$ the screening for inborn errors of the sorbitol pathway, particularly for sorbitol dehydrogenase deficieny in patients with hyperglycaemia or cataracts, seems quite attractive. This inborn error could lead to sorbitol accumulation in the lenses, among other tissues, and eventually to cataracts, like galactokinase or galactose-1phosphate uridyltransferase deficiencies lead to cataracts through galactitol accumulation. The diagnosis of both galactokinase and galactose-1phosphate uridyltransferase deficiencies is carried out in RBC. ${ }^{8}$

To the best of our knowledge, two quantitative

Accepted for publication 6 January 1983 methods, both spectrophotometric assays, for RBC-sorbitol dehydrogenase activity have been previously described. ${ }^{2}$ In one of them, ${ }^{2}$ the backward reaction from fructose to sorbitol is directly estimated, however, the RBC sorbitol dehydrogenase activity is only about $30 \%$ of the activity in the forward direction. ${ }^{7}$ The other method ${ }^{7}$ is an indirect two-stage assay designed to estimate activity in haemolysates, whose high optical density precludes direct optical assay of the enzyme. Although this assay is adequate for the measurement of RBCsorbitol dehydrogenase activity, it is expensive and time-consuming. Since we are interested in the quantification of sorbitol dehydrogenase activity in large number of individuals, we sought for a rapid, simple and less expensive assay. In the new assay described in this paper, the NADH formed as a result of the sorbitol to fructose oxidation in presence of $\mathrm{NAD}^{+}$and catalysed by $\mathrm{RBC}$-sorbitol dehydrogenase is measured in a filter fluorimeter.

\section{Material and methods}

The composition of the assay mixture for the fluorimetric method is based with slight modifications, on the one used in the first-step of the two-stage spectrophotometric assay of Barretto and Beutler. ${ }^{7}$ One $\mathrm{ml}$ of this mixture is prepared by mixing $100 \mu \mathrm{l} 1 \mathrm{M}$, Tris- $\mathrm{HCl}, \mathrm{pH} 8.0 ; 100 \mu \mathrm{l} 50 \mathrm{mmol}$ $\mathrm{NAD}^{+} ; 100 \mu \mathrm{l} 200 \mathrm{mmol} \mathrm{MgCl}{ }_{2} ; 500 \mu 1200 \mathrm{mmol}$ sorbitol; and water to a total volume of $1.0 \mathrm{ml}$. Blood collected in heparin was obtained from pro- 
fessional blood donors. The RBC were washed three times in cold saline solution and the buffy coat was removed. The red cells were diluted with two volumes of cold water and haemolysed by freezing in a dry-ice-acetone bath and thawing, for three times. The fluorescent assay was carried out in these lysates.

\section{PROCEDURE}

The procedure was similar to the Beutler's fluorimetric method for galactose-1-phosphate uridyltransferase activity. ${ }^{9}$ The assay is carried out by placing $200 \mu \mathrm{l}$ of the substrate mixture in a test tube $(13 \times 100 \mathrm{~mm})$ with the addition of $20 \mu \mathrm{l}$ of haemolysate followed by incubation at $37^{\circ} \mathrm{C}$ for 60 min. A blank system without sorbitol was included for each sample. The reaction was stopped by diluting $20 \mu \mathrm{l}$ of the incubation mixture in $4 \mathrm{ml}$ of $0.01 \mathrm{M}$ potassium phosphate buffer $\mathrm{pH} 7 \cdot 4$. The diluted incubation mixture is transferred to a $10 \mathrm{~mm}$ (inner diameter) round Turner photofluorimeter with a Turner No 110-811 (7-60) primary and No 110 817 (8) secondary filters. The fluorimeter was adjusted to read zero with the dummy cuvette. The fluorescence of the blank system was subtracted from the fluorescence of the complete system. The diluted reaction mixture was then transferred to a 0.5 by 4 inches $(11.60 \mathrm{~mm}$ inner diameter) Bausch and Lomb Spectronic 20 colorimeterspectrophotometer cuvette, and the optical density was determined at $410 \mathrm{~nm}$ against a buffer blank to estimate the $\mathrm{Hb}$ content. Sorbitol dehydrogenase activity (E) in $\mu \mathrm{mol}$ of product formed per gramme of $\mathrm{Hb}$ per hour is obtained as follows:

$$
\mathrm{E}=\frac{\mathrm{FC}}{\mathrm{A}}
$$

where $F=$ the net fluorescence of the sample;

$\mathrm{C}=$ the calibration factor;

$A=$ the absorbance of the diluted system at $410 \mathrm{~nm}$.

Calibration of the method was carried out according to the procedure used by Beutler and Mitchell' in the fluorimetric assay for galactose-1-phosphate uridyltransferase. Serial dilutions of a solution of known NADH concentration were prepared and fluorescence determined in the fluorimeter; serial dilutions of the haemoglobin solution of known concentration were prepared and absorbance determined at $410 \mathrm{~nm}$ in the colorimeter. The fluorescence readings were plotted against the NADH concentrations and the absorbance readings against haemoglobin $(g / 1)$. The fluorescence reading given by $1 \mu \mathrm{mol}$ NADH is read from the respective curve and designated $F_{1}$. The absorbance given by a $0.1 \mathrm{~g} / 1$ solution of haemoglobin is read from the curve and is designated $A_{1}$. The calibration factor $(C)$ is calculated as follows:

$$
\mathrm{C}=\frac{10 \times \mathrm{A}_{1}}{\mathrm{~F}_{1}}
$$

Barretto and Beutler spectrophotometric assay for sorbitol dehydrogenase activity ${ }^{7}$ in blood samples obtained from 50 professional blood donors was carried out for reference purposes.

Results

Sorbitol dehydrogenase in erythrocytes is stable for

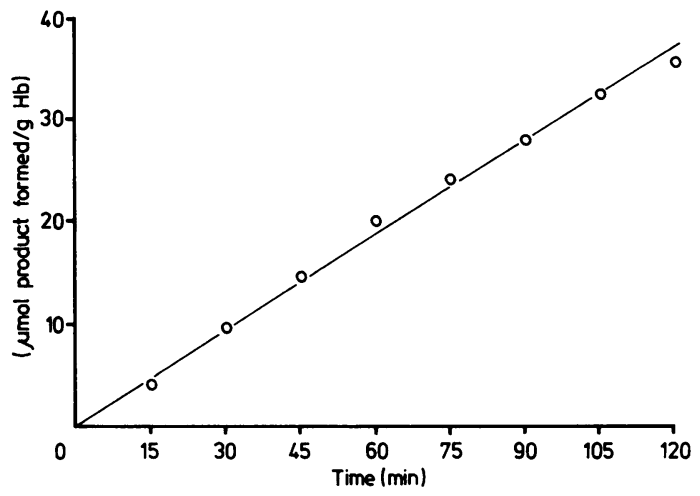

Fig. 1 The effect of incubation time on the enzyme velocity. The reaction system was prepared as described in the text using haemolysate diluted $1 / 3(\mathrm{Hb} 7-10 \mathrm{~g} \%)$ and incubated for two hours. Aliquot parts were removed from the incubating mixture each 15 min and the $\mu$ mol product formed per $\mathrm{g} \mathrm{Hb}$ estimated as stated in the text. Each point represents the mean value of an assay for triplicate.

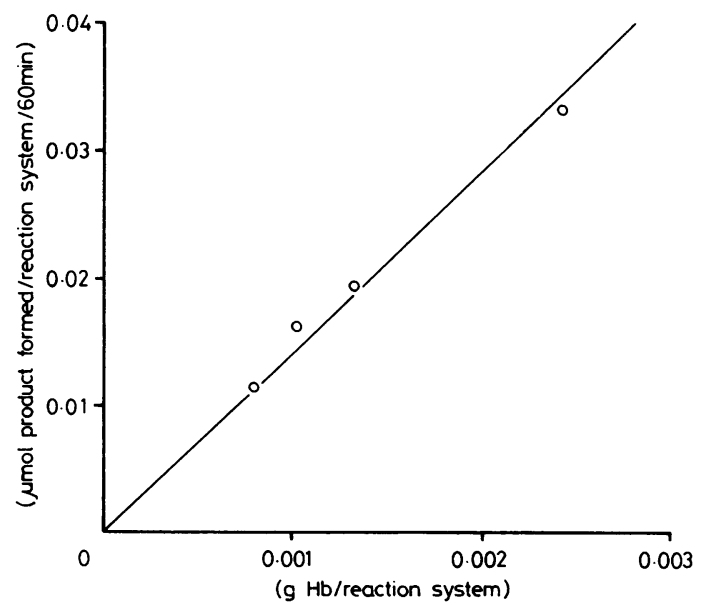

Fig. 2 The effect of the enzyme activity on the enzyme velocity. The reaction systems were prepared as described in the text using different dilutions of a haemolysate and incubated for one hour. Both the $\mu \mathrm{mol}$ product and the $\mathrm{Hb}$ concentration by reaction system were estimated from $N A D H$ and $H b$ calibration curves respectively. Each point represents the mean value of an assay for triplicate. 


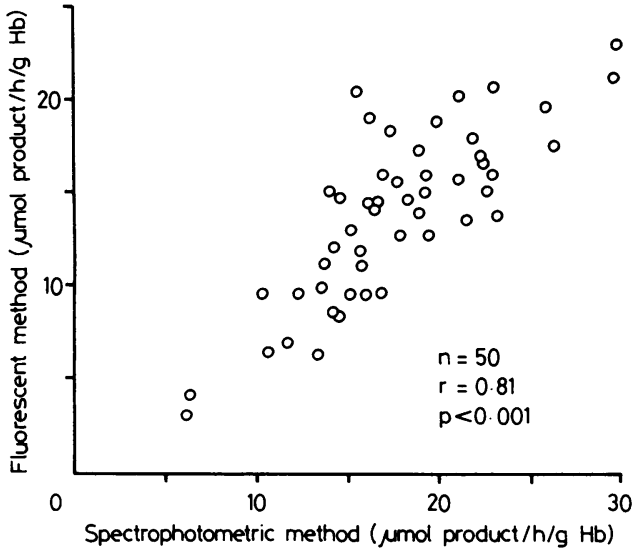

Fig. 3 Correlation between the quantitative fuorescent method and the Barretto and Beutler spectrophotometric two-stage assay. Each point represents the mean value of assays performed by duplicate.

at least five days when whole blood is kept at $4^{\circ} \mathrm{C}$. The enzyme tests were repeated at least twice within five days in several samples. The enzyme activity was linear with incubation times for at least two hours (Fig. 1). If sorbitol is omitted from the reaction mixture, little fluorescence develops, and there is no increase even after two hours of incubation. The enzyme activity was proportional to $\mathrm{Hb}$ concentrations up to at least $12 \mathrm{~g} / \mathrm{dl}$ in the haemolysate, which correspond to $0 \cdot 0024$ by reaction system (Fig. 2). The data depicted in Fig. 2 indicate that at the concentration used the presence of haemoglobin does not result in the quenching of fluorescence. In the Beutler's fuorimetric assay for galactose-1phosphate uridyltransferase activy whole blood is used as the enzyme source and 1/200 dilution of it produces less that $15 \%$ quenching of the fluorescence from $1 \mu \mathrm{mol}$ NADPH. ${ }^{9}$

An incubation time of $60 \mathrm{~min}$ and haemolysate diluted 1/3 (Hb 7-10 g/dl) were selected for the routine assay. The results of sorbitol dehydrogenase measurements carried out by duplicate in samples from 50 individuals, by both fluorescent quantitative assay and the spectrophotometric two-stage assay of Barretto and Beutler, ${ }^{7}$ are shown in Fig. 3. A good correlation between both methods was obtained. Precision (95\% limits) of the fluorimetric method was $\pm 25.7 \%$ and the range of values for the studied population was 3.18-23.04 $\mu \mathrm{mol}$ product/h/g Hb.

\section{Discussion}

Several studies about the role of the polyol pathway in the metabolism of human RBC have been reported $^{3-610}$ and the sorbitol dehydrogenase of these cells has been partially purified and character- ised. ${ }^{7}$ Furthermore, by hybridisation of human and hamster cells the locus of sorbitol dehydrogenase has been provisionally assigned to chromosome 15 at the pter $\rightarrow$ q21 band. ${ }^{11}$ However, little is known about the biochemical genetics of human sorbitol dehydrogenase. Charlesworth has studied red cell sorbitol dehydrogenase in 665 individuals and reports only one rare electrophoretic variant. ${ }^{12}$ Our group has demonstrated electrophoretic polymorphism of the enzyme in human seminal plasma ${ }^{13}$ and RBC-sorbitol dehydrogenase deficiency in a family with congenital cataracts. ${ }^{14}$ This enzymatic defect was detected by a qualitative fluorescent screening test later confirmed by both enzymatic quantitative assays and methaemoglobin reduction by intact RBC incubated in presence of sorbitol. ${ }^{14}$ The results did not define a clear cataract-sorbitol dehydrogenase deficiency aetiopathogenic relation but activity polymorphism in RBC-sorbitol dehydrogenase was very likely. This finding would be highly relevant not only to the study of cataracts but of other major complications in diabetes, such as neuropathy and glomerulosclerosis since several studies have implicated the possible contribution of sorbitol in their pathogenesis. ${ }^{15-18}$

The present method correlates satisfactorily with the indirect spectrophotometric assay and offers several advantages: it is rapid, simple and inexpensive. It may be useful to screen for sorbitol dehydrogenase deficiency in a large number of individuals to determine the extent of sorbitol dehydrogenase activity polymorphism and to define its role in the development of cataracts and the major diabetes complications.

\section{References}

' van Heyningen R. Sugar alcohols in the pathogenesis of galactose and diabetic cataracts. In: The eye and inborn errors of metabolism. Birth Defects 1976;XII:295-303.

${ }^{2}$ Morsches B, Holzman H, Bettingen C. Zum Nachweis der Sorbitdehydrogenase in menschlichen Erythrocyten. Klin Wochenschr 1969;47:672-3.

${ }^{3}$ Morrison AD, Clements RS Jr, Travis SF, Oski F, Winegrad AI. Glucose utilisation by the polyol pathway in human erythrocytes. Biochem Biophys Res Commun 1970;40:199-205.

${ }^{4}$ Beutler E, Guinto E. The reduction of glyceraldehyde by human erythrocytes. L-hexonate dehydrogenase activity. J Clin Invest 1974;53:1258-64.

${ }^{5}$ Travis SF, Morrison AD, Clements RS Jr, Winegrad AI, Oski F. Metabolic alterations in the human erythrocyte produced by increases in glucose concentration. The role of the polyol pathway. J Clin Invest 1971;50:2104-12.

- Torrance JD. The role of fructose in restoration of organic phosphate compounds in outdated bank blood. J Lab Clin Med 1973;82:489-99.

' Barretto OCO, Beutler E. The sorbitol-oxidizing enzyme of red blood cells. J Lab Clin Med 1975;85:645-9.

${ }^{8}$ Segal S. Disorders of galactose metabolism. In: The metabolic basis of inherited disease. New York: McGraw-Hill, 1978:160. 
' Beutler E, Mitchell M. New rapid method for the estimation of red cell galactose-1-phosphate uridyl transferase activity. $J$ Lab Clin Med 1968;72:527-32.

1" Travis SF, Morrison AD, Clements RS Jr, Winegrad AI, Oski F. The role of the polyol pathway in methaemoglobin reduction in human red cells. Br J Haematol 1974;27:597-605.

"Donald LJ, Wang HS, Hamerton JL. Assignment of the sorbitol dehydrogenase locus to human chromosome 15 pter $\rightarrow \mathrm{q} 21$. Biochem Genet 1980;18:425-31.

${ }^{12}$ Charlesworth D. Starch-gel electrophoresis of four enzymes from human red blood cells: glyceraldehyde-3-phosphate dehydrogenase, fructoaldolase, glyoxalase 11 and sorbitol dehydrogenase. Ann Hum Genet 1972;35:477-84.

${ }^{13}$ Ibarra B, González-Quiroga G, Vaca G, Díaz M, Rivas F, Cantú JM. Sorbitol dehydrogenase (EC 1.1.1.14) polymorphism in human seminal plasma. Ann Genet (Paris) 1982;25:53-5.

14 Vaca G, Ibarra B, Bracamontes M, et al. Red blood cell sorbitol dehydrogenase deficiency in a family with cataracts. Hum Genet 1982;61:338-41.

is Gabbay KH, Merola LO, Field RA. Sorbitol pathway: presence in nerve and cord with substrate accumulation in diabetes. Science 1966;151:209-10.

${ }^{16}$ Gabbay KH. The sorbitol pathway and the complications of diabetes. $N$ Engl J Med 1973;288:831-6.

${ }^{17}$ Gabbay KH. Hyperglycemia, polyol metabolism and complications of diabetes mellitus. Annu Rev Med 1975;26:521-36.

${ }^{1 *}$ Corder CN, Braughler JM, Culp PA. Quantitative histochemistry of sorbitol pathway in glomeruli and small arteries of human diabetic kidney. Folia Histochem (ytochem (Krakow) 1979;17:137-46.

Requests for reprints to: Gerardo Vaca, Apartado Postal 1-3838, Guadalajara, Jalisco, Mexico. 